\title{
Attenuation of Central Pacific EI Niño Amplitude by North Pacific Sea Surface Temperature Anomalies
}

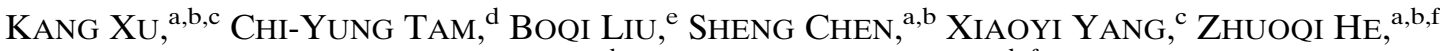 \\ QIANG XIE, ${ }^{\mathrm{g}, \mathrm{h}}$ AND WEIQIANG WANG ${ }^{\mathrm{a}, \mathrm{b}, \mathrm{f}}$ \\ ${ }^{a}$ State Key Laboratory of Tropical Oceanography, South China Sea Institute of Oceanology, \\ Chinese Academy of Sciences, Guangzhou, China \\ ${ }^{b}$ Southern Marine Science and Engineering Guangdong Laboratory (Guangzhou), Guangzhou, China \\ ${ }^{c}$ State Key Laboratory of Marine Environmental Science, Xiamen University, Xiamen, China \\ ${ }^{d}$ Earth System Science Programme, The Chinese University of Hong Kong, Hong Kong, China \\ ${ }^{e}$ State Key Laboratory of Severe Weather, and Institute of Climate System, Chinese Academy \\ of Meteorological Sciences, Beijing, China \\ ${ }^{f}$ Innovation Academy of South China Sea Ecology and Environmental Engineering, \\ Chinese Academy of Sciences, Guangzhou, China \\ ${ }^{g}$ Institute of Deep-Sea Science and Engineering, Chinese Academy of Sciences, Sanya, China \\ ${ }^{h}$ Laboratory for Regional Oceanography and Numerical Modeling, Qingdao National Laboratory \\ for Marine Science and Technology, Qingdao, China
}

(Manuscript received 13 October 2019, in final form 10 March 2020)

\begin{abstract}
There exists a pronounced asymmetry between the amplitudes of central Pacific (CP) and eastern Pacific (EP) El Niño sea surface temperature anomalies (SSTA). The present study examines such an asymmetry and its relationship with the North Pacific SSTA. Results indicate that the weaker CP El Niño amplitude can be attributed to the weaker anomalous zonal wind response to the east-west equatorial SSTA gradient during its growing phase compared with EP El Niño. Furthermore, the occurrence of CP El Niño is closely associated with southwesterly surface wind anomalies in the subtropical North Pacific, as well as ocean warming reminiscent of the North Pacific Gyre Oscillation (NPGO) pattern in its vicinity. Both the observations as well as the pacemaker experiments with a coupled global climate model suggest that the anomalous low-level southwesterlies, induced by the North Pacific Oscillation (NPO)-like atmospheric variability, can enhance anomalously positive SST signals and extend them southwestward to the central equatorial Pacific via the wind-evaporation-SST feedback. This will further attenuate the atmospheric response to zonal SSTA gradient, and hence weaken the amplitude of CP El Niño. Therefore, anomalous low-level southwesterlies over the subtropical North Pacific can effectively act as a conduit for tropical-subtropical air-sea interaction in that region, and can play an important role in limiting the intensity of CP El Niño.
\end{abstract}

\section{Introduction}

El Niño-Southern Oscillation (ENSO) is a coupled ocean-atmosphere interaction in the tropical Pacific, and is widely recognized as the most important contributor to climate variability on the interannual time scale (Rasmusson and Carpenter 1982; Wang et al. 2017). Despite originating in the tropics, ENSO events can affect the global climate through atmospheric teleconnections (McPhaden et al. 2006; Yang et al. 2018). Each El Niño event differs in their essential properties,

Corresponding author: Weiqiang Wang, weiqiang.wang@scsio. ac.cn such as their temporal evolution, magnitude, and the spatial pattern of tropical Pacific sea surface temperature (SST) anomalies (Newman et al. 2011; Yu and Giese 2013; Capotondi et al. 2015; Chen et al. 2015; Yu et al. 2017; Hu and Fedorov 2018; Timmermann et al. 2018; Ashok et al. 2017). These complexities of the ENSO properties could cause distinct global climate anomalies via the different Rossby wave trains (Beyene and Jain 2018; Xu et al. 2019a).

Recently, a new type of El Niño has been identified, referred to as "Date Line El Niño" (Larkin and Harrison 2005), "El Niño Modoki”" (Ashok et al. 2007), "Central Pacific El Niño" (Yu and Kao 2007; Kao and Yu 2009) or "Warm Pool El Niño" (Kug et al. 2009). 
This El Niño type is primarily characterized by strongest warm SST anomalies (SSTA) in the central tropical Pacific and cold SSTA in the western and eastern tropical Pacific, making it very different from the traditional El Niño in which the warm SSTA are centered in the eastern equatorial Pacific (Ashok et al. 2007; Kao and Yu 2009; Ren and Jin 2011; Xu et al. 2012, 2017b; Capotondi et al. 2015). In the present study, the two types of El Niño events are referred to as the eastern Pacific (EP) and central Pacific (CP) El Niño, according to their different recurrent SSTA patterns. Compared with EP El Niño, CP El Niño displays different climate impacts, presumably due to its distinct diabatic heating patterns and remote influences over the world's oceans (e.g., Kumar et al. 2006; Weng et al. 2007, 2009; Zhang et al. 2011, 2014; Feng et al. 2010, 2011; Feng and Li 2011; Yuan and Yang 2012; Xu et al. 2013, 2019a).

Besides the difference in the location of warm SSTA, asymmetric amplitudes of EP and CP El Niño also result in different climate impacts (Newman et al. 2011; Yu et al. 2012b; Zhang et al. 2013; Zheng et al. 2016), and also their seasonal predictability (Sohn et al. 2016, 2019), over the globe. The variability in ENSO amplitude has been widely studied. Some studies have concluded that the nonlinear internal dynamics of ENSO (Timmermann 2003; Xie and Jin 2018) and the nonlinearity of ENSO, particularly the El Niño-La Niña asymmetry (An and Jin 2004), are responsible for the ENSO variability. Other studies have attributed the different ENSO types and their variability to changes in the tropical Pacific mean state (McPhaden et al. 2011; Chung and Li 2013; Kang et al. 2014; He et al. 2020). Kang and Kug (2002) indicated that ENSO amplitude is very sensitive to the location of anomalous zonal wind stress in the equatorial central Pacific, since the excited oceanic Rossby wave mainly controls the delayed oscillator-related negative feedback. Zheng et al. (2014) suggested that cloud radiative processes play a key role in the amplitude asymmetry between CP and EP El Niño. Hu and Fedorov (2018) revealed that the crossequatorial winds in the eastern tropical Pacific could modulate tropical Pacific mean state and variability, and then suppress ENSO variability via ocean dynamical processes.

Much attention has been also paid to the feedback of tropical-extratropical interactions $(\mathrm{Gu}$ and Philander 1997; Di Lorenzo et al. 2010, 2015; Chen and Wallace 2015) and the influence of North Pacific atmospheric forcing (Yu and Kim 2011; Yeh et al. 2015; Zheng et al. 2016; Yu and Fang 2018) on ENSO diversity and variability. Di Lorenzo et al. (2010) described the potential impacts and connections of extratropical climate on $\mathrm{CP}$ El Niño on decadal time scales, and suggested that much of the decadal climate variability over the North Pacific is driven by tropical Pacific climate variability. Di Lorenzo et al. (2015) further hypothesized that the Pacific climate variability arises from the combined action of ENSO and the Pacific meridional mode. Yu et al. (2012a) and Yeh et al. $(2015,2018)$ argued that North Pacific Oscillation (NPO)-like atmospheric circulation has been more influential in the tropical Pacific after the mid-1990s, leading to the remarkable increase in occurrence of CP El Niño, because of the windevaporation-SST (WES; Xie and Philander 1994) feedback in the subtropical northeastern Pacific. Vimont et al. (2003) first described this tropical-extratropical interaction process by the seasonal footprinting mechanism, and Yu and Fang (2018) further emphasized it is a key source of ENSO complexity and asymmetry. Xu et al. (2019b) also suggested that the dominant atmospheric mode exchanges between the NPO and the Aleutian low are responsible for the decadal changes in El Niño amplitude via the weakening responses of anomalous zonal wind stress to the equatorial SSTA gradient.

Given the importance of North Pacific climate variability to El Niño diversity, this study seeks to explore how North Pacific SSTA might affect El Niño characteristics, especially CP El Niño amplitude. Although previous studies have indicated a possible linkage between the North Pacific SSTA and ENSO at different time scales (e.g., Di Lorenzo et al. 2010; Yu and Kim 2011; Yu et al. 2012a; Yeh et al. 2015; Xu et al. 2019b), the associated physical mechanism has not been sufficiently elucidated. Here we try to investigate how North Pacific SSTA influences CP El Niño amplitude by conducting coupled model experiments. The remainder of the paper is organized as follows. The datasets, methods, and model utilized in this study are briefly introduced in section 2. Section 3 describes the contrasting amplitudes for EP and CP El Niño events and their related dynamic and thermodynamic processes. Section 4 describes the mechanism of how North Pacific SSTA might modulate CP El Niño amplitude, based on observations and model experiments. A discussion and summary are presented in section 5 .

\section{Data and methodology}

\section{a. Observational datasets}

Global monthly SST with a horizontal resolution of $1^{\circ} \times 1^{\circ}$ was extracted from the Hadley Centre Global Sea Ice and Sea Surface Temperature (HadISST version 1.1; Rayner et al. 2003) analysis dataset. Monthly atmospheric reanalysis data, including three-dimensional wind, surface heat flux, and sea level pressure (SLP), were obtained from the U.S. National Centers for 
Environmental Prediction-National Center for Atmospheric Research (NCEP-NCAR) reanalysis products (Kalnay et al. 1996). In these datasets, surface variables are stored on a global T62 Gaussian grid, while the isobaric variables are available at a horizontal resolution of $2.5^{\circ} \times 2.5^{\circ}$ and extend from 1000 to $10 \mathrm{hPa}$ with 17 vertical pressure levels. Wind stress data were taken from the Simple Ocean Data Assimilation (SODA, version 2.2.4) package (Carton and Giese 2008), with a horizontal resolution of $0.5^{\circ} \times 0.5^{\circ}$. To examine the relative contributions of the dynamic and thermodynamic processes during the growth stages of two types of El Niño, we used subsurface ocean data derived from the European Centre for Medium-Range Weather Forecasts (ECMWF) Ocean Reanalysis System 4 (ORAS4) product (Balmaseda et al. 2013), which covers the global ocean with a horizontal resolution of $1^{\circ} \times 1^{\circ}$ and 42 vertical levels. The analysis period of the above monthly datasets covers 1958-2016, with the exception of the SODA2.2.4 dataset, which covers the period 1958-2010. All the monthly mean variables were smoothed by taking 3-month running averages to exclude subseasonal variability, and anomalies of all variables were calculated as the deviation from the corresponding mean seasonal cycle.

\section{b. Methods}

The Niño-3 index and El Niño Modoki index (EMI) were used to characterize the EP and CP ENSO cycle and interannual variation, respectively. The Niño-3 index is defined by the area-averaged SSTA over the tropical eastern Pacific region $\left(150^{\circ}-90^{\circ} \mathrm{W}, 5^{\circ} \mathrm{S}-5^{\circ} \mathrm{N}\right)$, and the EMI is defined (Ashok et al. 2007) as

$$
\mathrm{EMI}=[\mathrm{SSTA}]_{\mathrm{C}}-0.5 \times\left([\mathrm{SSTA}]_{\mathrm{E}}+[\mathrm{SSTA}]_{\mathrm{W}}\right),
$$

where the square brackets with a subscript in Eq. (1) represent the area-mean SSTA averaged in the central (C: $\left.165^{\circ} \mathrm{E}-140^{\circ} \mathrm{W}, 10^{\circ} \mathrm{S}-10^{\circ} \mathrm{N}\right)$, eastern $\left(\mathrm{E}: 110^{\circ}-70^{\circ} \mathrm{W}\right.$, $\left.15^{\circ} \mathrm{S}-5^{\circ} \mathrm{N}\right)$, and western (W: $\left.125^{\circ}-145^{\circ} \mathrm{E}, 10^{\circ} \mathrm{S}-20^{\circ} \mathrm{N}\right)$ tropical Pacific regions, respectively. Following Feng et al. (2017), we made use of these indices to classify the two types of El Niño events based on fluctuations of 0.8 standard deviations in these two indices. An EP (CP) El Niño case was identified wherever the normalized Niño3 index (EMI) is more positive than the normalized EMI (Niño-3 index) in the same December-February (DJF) season. According to these criteria, eight EP El Niño (1965/66, 1972/73, 1976/77, 1982/83, 1986/87, 1991/92, 1997/98, and 2015/16) and eight CP El Niño events (1958/59, 1963/64, 1968/69, 1977/78, 1994/95, 2002/03, 2004/05, 2009/10) were classified during the period 19582016. Although the years 1967/68, 1979/80, 1990/91, 1992/
93, and 2014/15 meet the criteria of CP El Niño, they are not counted as CP El Niño cases because they are not well-recognized El Niño events according to NOAA.

Owing to the limited number of observed El Niño events, and following Zheng et al. (2014), the "robustness regression" method using the ordinary least squares with no weighting function was applied to investigate the regressed calculations during the growth season of the El Niño events. This method gives more robust estimates of the standard errors, and meets the assumptions on the normality and homogeneity of the variance of the residuals (Holland and Welsch 1977). In addition, we also performed a mixed layer heat budget analysis to examine the relative contributions of the different dynamic and thermodynamic processes during the growth season of the two types of El Niño. Following Li et al. (2002), the mixed layer temperature budget can be described by the following equation:

$$
\begin{aligned}
\frac{\partial T^{\prime}}{\partial t}= & -u^{\prime} \frac{\partial \bar{T}}{\partial x}-\bar{u} \frac{\partial T^{\prime}}{\partial x}-u^{\prime} \frac{\partial T^{\prime}}{\partial x}-v^{\prime} \frac{\partial \bar{T}}{\partial y}-\bar{v} \frac{\partial T^{\prime}}{\partial y}-v^{\prime} \frac{\partial T^{\prime}}{\partial y} \\
& -w^{\prime} \frac{\partial \bar{T}}{\partial z}-\bar{w} \frac{\partial T^{\prime}}{\partial z}-w^{\prime} \frac{\partial T^{\prime}}{\partial z}+Q+R,
\end{aligned}
$$

where the bars and primes represent the climatologic mean variables and the anomaly departure from the climatological mean, respectively; $T, u, v$, and $w$ indicate the oceanic temperature and the zonal, meridional, and vertical velocities averaged over the mixed layer, respectively. The first nine terms on the right-hand side of Eq. (2) represent the oceanic heat advection in the zonal, meridional, and vertical directions, respectively, the term $(Q)$ after the ocean advection terms represents the surface heat flux term, and the last term $(R)$ denotes the residual term.

\section{c. Model description}

We used the NCAR Community Earth System Model (CESM version 1.2.2; Hurrell et al. 2013), a state-of-theart fully coupled global climate model, to investigate the responses of El Niño activities to the observed SST anomalies in the North Pacific. The atmospheric model used in CESM is the Community Atmosphere Model [version 4 (CAM4); Neale et al. 2013], with a horizontal resolution of $1.9^{\circ}$ latitude $\times 2.5^{\circ}$ longitude and a 26-layer hybrid pressure sigma coordinate in the vertical direction. The ocean model is version 2 of the Parallel Ocean Program (POP2; Smith et al. 2010) developed at Los Alamos National Laboratory (LANL) with $1^{\circ}$ horizontal resolution and enhanced meridional resolution $\left(1 / 3^{\circ}\right)$ in the tropics, and 60 vertical levels. The sea ice model is 
the LANL Community Ice Code [version 4 (CICE4); Hunke and Lipscomb 2010] and shares the same horizontal grid as the ocean model. The land surface model employed by the CESM is the Community Land Surface Model [version 4.0 (CLM4); (Oleson et al. 2010] and has the same horizontal grid as CAM4. The fully coupled control simulation was integrated for 1200 years without apparent climate shifts. We then used the last 200 years of data to assess the capability of used CESM model and found it has good capability in capturing the El Niño diversity and their amplitude asymmetry. Details of the numerical sensitivity experiments will be given in section $4 b$.

\section{Contrasting amplitudes of EP and CP EI Niño events}

\section{a. Pronounced amplitude asymmetry}

To ensure the method used in this study can successfully distinguish EP and CP El Niño events, we first show the observed wintertime (DJF) mean composites of SSTA in the tropical Pacific during the peaks of the two types of El Niño events (Fig. 1). The EP El Niño-related SSTA exhibits a dipole pattern, with significant anomalous warming in the eastern-to-central tropical Pacific and cooling in the western tropical Pacific (Fig. 1a). In contrast, for the CP El Niño winters, the SSTA is characterized by warmer-than-normal temperatures in the central tropical Pacific and cold anomalies in the southeastern and western tropical Pacific (Fig. 1b). Comparison between Figs. 1a and $1 \mathrm{~b}$ reveals the much smaller mean amplitude of CP El Niño compared with EP El Niño in boreal winter. Meanwhile, for CP El Niño the area of significant positive SSTA is also located in the subtropical northeastern Pacific and extends to the central equatorial Pacific. This subtropical warming might contribute to the development of $\mathrm{CP} \mathrm{El}$ Niño, as inferred by Yu and Fang (2018) and Wang et al. (2019).

Figure 2 shows the difference in temporal evolution of the equatorial-mean SST and surface wind anomalies averaged between $5^{\circ} \mathrm{S}$ and $5^{\circ} \mathrm{N}$ associated with the two types of El Niño events. For the EP El Niño, the maximum warm SSTA of $+2.1^{\circ} \mathrm{C}$ appears in the eastern equatorial Pacific (east of $150^{\circ} \mathrm{W}$ ), accompanied by the stronger surface westerly over the central equatorial Pacific between $160^{\circ} \mathrm{E}-120^{\circ} \mathrm{W}$ (Fig. 2a). During the CP El Niño, however, the warm SSTA center of $+1.2^{\circ} \mathrm{C}$ occurs in the central equatorial Pacific (almost to the west of $150^{\circ} \mathrm{W}$ ), along with the prominent equatorial westerly anomalies between $140^{\circ} \mathrm{E}-160^{\circ} \mathrm{W}$ during its growth phase (Fig. 2b). In addition, there

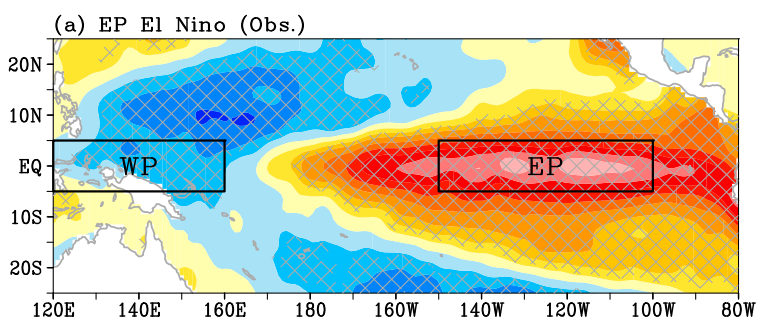

(b) CP El Nino (Obs.)

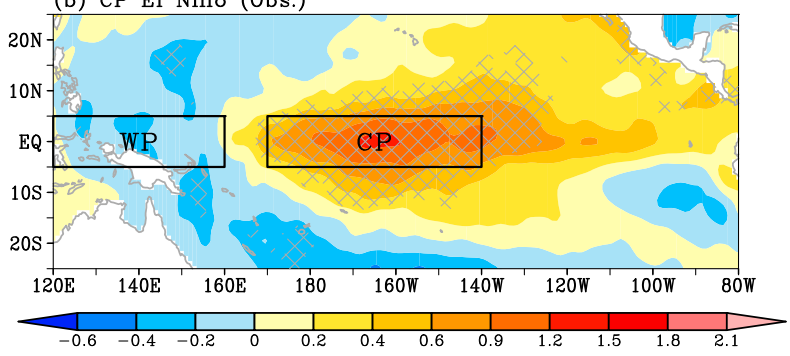

FIG. 1. The observed wintertime (DJF) SSTA $\left({ }^{\circ} \mathrm{C}\right)$ composites for the (a) EP and (b) CP El Niño events. Gray crosses denote values that are statistically significant at the $90 \%$ confidence level. The three rectangular boxes indicate the western $\left(120^{\circ}-160^{\circ} \mathrm{E}, 5^{\circ} \mathrm{S}-\right.$ $\left.5^{\circ} \mathrm{N}\right)$, central $\left(170^{\circ} \mathrm{E}-140^{\circ} \mathrm{W}, 5^{\circ} \mathrm{S}-5^{\circ} \mathrm{N}\right)$, and eastern $\left(150^{\circ}-100^{\circ} \mathrm{W}\right.$, $\left.5^{\circ} \mathrm{S}-5^{\circ} \mathrm{N}\right)$ regions of the equatorial Pacific and are termed the WP, $\mathrm{CP}$, and EP boxes, respectively.

are significant easterly anomalies over the eastern equatorial Pacific. Differences also exist in the timing of the developing and decaying phases of two types of El Niño. Based on significant SSTA greater than $+0.5^{\circ} \mathrm{C}$ (shown in Fig. 2), the EP (CP) El Niñorelated warm SST anomalies develop in early April (June) of the onset year, and decay after the following late June (April). This suggests that the life cycle of CP El Niño is remarkably shorter than that of EP El Niño, consistent with previous findings (Lee and McPhaden 2010; Zheng et al. 2014; Xu et al. 2017a). Therefore, CP El Niño events are prominently weaker and have a shorter lifespan than their EP El Niño counterparts.

Based on the DJF-mean locations of the maximum warm SSTA, the eastern $\left(150^{\circ}-100^{\circ} \mathrm{W}, 5^{\circ} \mathrm{S}-5^{\circ} \mathrm{N}\right)$ and central $\left(170^{\circ} \mathrm{E}-140^{\circ} \mathrm{W}, 5^{\circ} \mathrm{S}-5^{\circ} \mathrm{N}\right)$ equatorial Pacific are named the EP and CP boxes (shown in Fig. 1), respectively, and used to quantify the differences between the EP and CP El Niño events (Fig. 3). In DJF, the amplitude of the warm SSTA in central Pacific $\left(+0.79^{\circ} \mathrm{C}\right)$ for $\mathrm{CP}$ El Niño is about half of that in eastern Pacific $\left(+1.66^{\circ} \mathrm{C}\right)$ for EP El Niño events, revealing a pronounced amplitude asymmetry. It is noteworthy that the amplitude differences are statistically significant in the developing and mature phases of El Niño events (Fig. 3); here the "growth season" is therefore defined as JuneDecember in the onset year. 


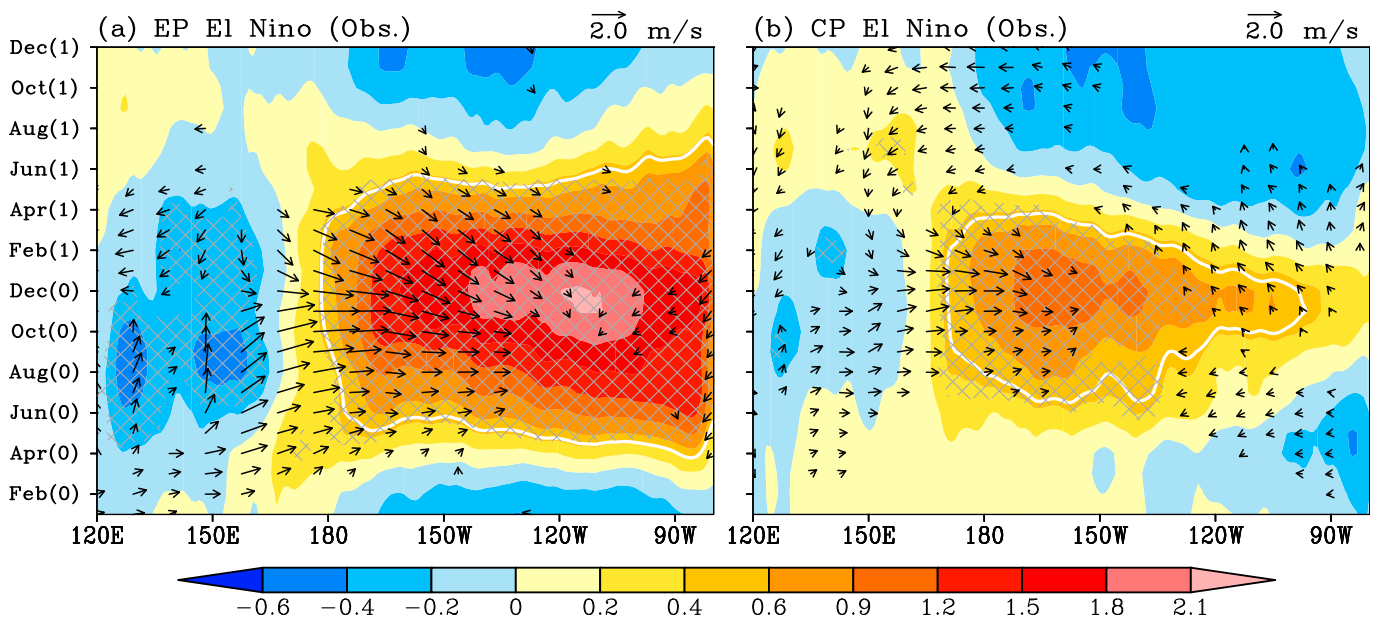

FIG. 2. Time-longitude cross section of the composite SSTA (shading; ${ }^{\circ} \mathrm{C}$ ) and 10 - $\mathrm{m}$ wind (vectors; $\mathrm{m} \mathrm{s}^{-1}$ ) at the equator (averaged from $5^{\circ} \mathrm{S}$ to $5^{\circ} \mathrm{N}$ ) for the (a) EP and (b) CP El Niño events, where (0) indicates the El Niño year and (1) represents the following year. White contours indicate the regions with the SST anomalies greater than $+0.5^{\circ} \mathrm{C}$. The gray crosses and black vectors respectively denote SST and $10-\mathrm{m}$ wind anomalies that are statistically significant at the $95 \%$ confidence level.

\section{b. Different dynamic and thermodynamic processes}

Since the warm SSTA during the growth season of EP and $\mathrm{CP}$ El Niño is primarily the result of oceanic process (An and Jin 2001; Kug et al. 2009; Yu et al. 2010; Ren and Jin 2013; Su et al. 2014; Xu et al. 2017a), we focus on the mixed layer ocean temperature budget analysis [see Eq. (2)] to examine the physical processes for EP and CP El Niño events. In contrast to the use of a constant mixed layer depth $H$ value in some previous studies (Kug et al. 2009; Yu et al. 2010), here we used a spatially and temporally varying $H$ defined as the depth where ocean temperature is $0.5^{\circ} \mathrm{C}$ lower than the surface value. Figure 4 shows the relative contributions of oceanic and thermodynamic processes averaged over the EP and CP boxes to the two types of El Niño. For the growth season of both EP and CP El Niño, the three-dimensional (3D) temperature advection terms mainly contribute to the mixed layer ocean temperature warming while the surface heat flux anomalies act as a damping effect. Note that the sum of the 3D ocean advection and surface heat

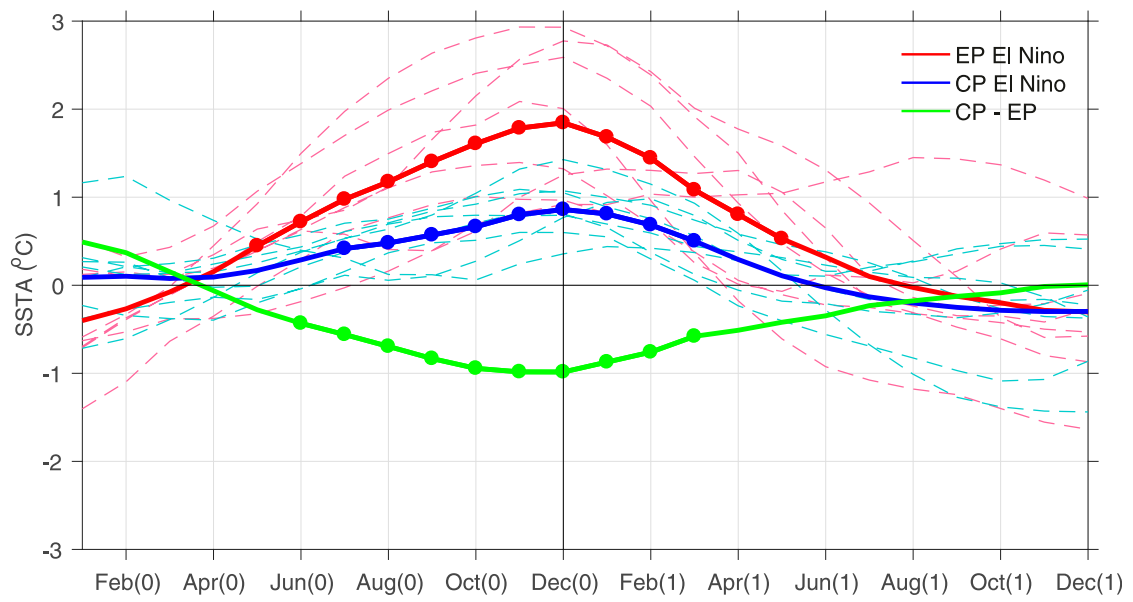

FIG. 3. The observed SSTA $\left({ }^{\circ} \mathrm{C}\right)$ evolution for the key region of the EP $\left(150^{\circ}-100^{\circ} \mathrm{W}, 5^{\circ} \mathrm{S}-\right.$ $5^{\circ} \mathrm{N}$; red bold curve) and CP El Niño $\left(170^{\circ} \mathrm{E}-140^{\circ} \mathrm{W}, 5^{\circ} \mathrm{S}-5^{\circ} \mathrm{N}\right.$; blue bold curve) events, and their difference (green bold curve). The time axis is from January of the onset year (0) to December of the following year $(+1)$. Individual EP and CP El Niño events are represented by thin colored dashed curves, with closed circles indicating that the corresponding differences pass the $90 \%$ confidence level based on the Student's $t$ test. 

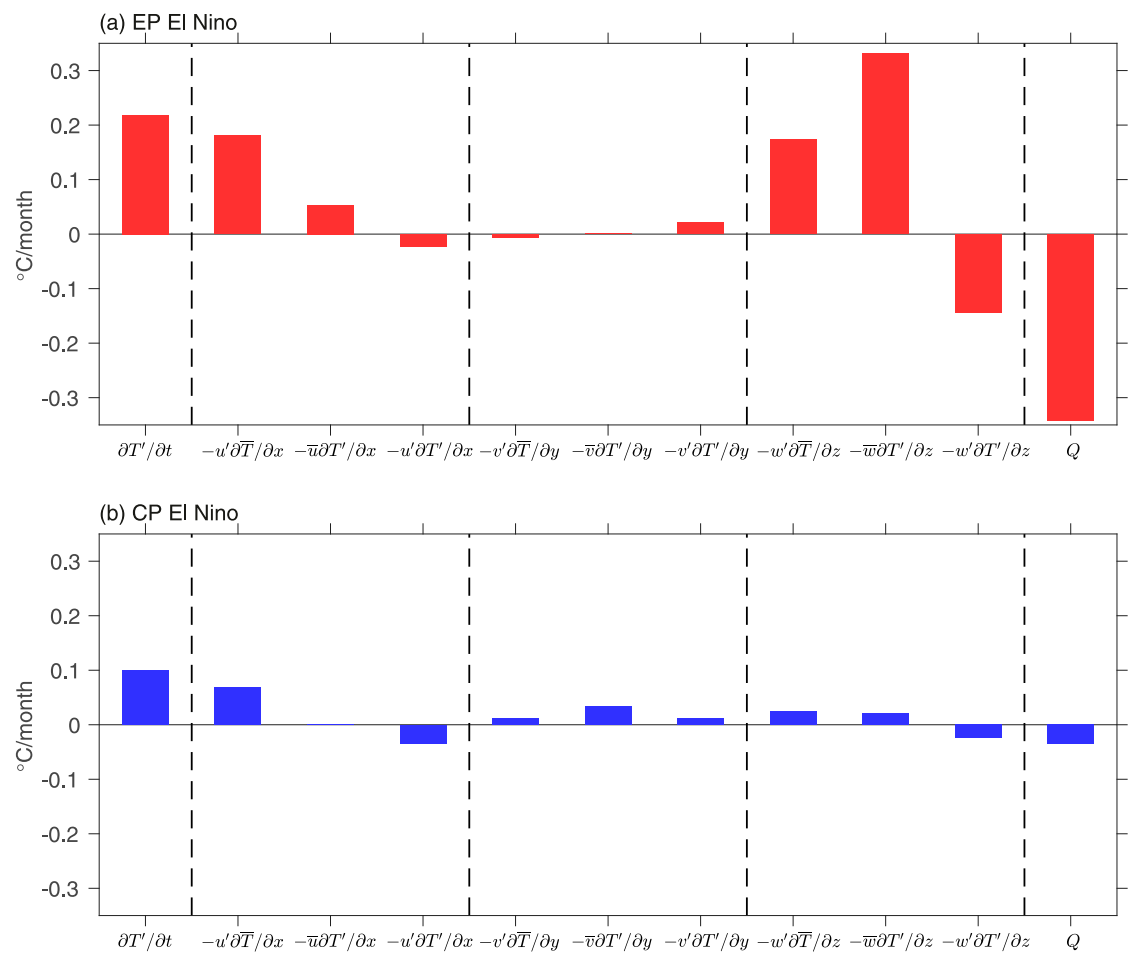

FIG. 4. The observed mixed layer temperature tendency, the individual zonal, meridional, and vertical advection terms, and the surface heat flux term $\left({ }^{\circ} \mathrm{C} \mathrm{month}{ }^{-1}\right)$ averaged over the $\mathrm{EP}$ and $\mathrm{CP}$ boxes during the growth season of (a) EP and (b) CP El Niño events.

flux terms approximately equals the mixed layer temperature tendency (Fig. 4), suggesting that the mixed layer heat budget analysis is quite balanced despite the uncertainties in surface heat fluxes and oceanic subgrid processes. This indicates that the use of variable $H$ can reduce uncertainties in the heat budget. Also, the mixed layer temperature growth rate in the growth season is $+0.21^{\circ} \mathrm{C}$ month $^{-1}$ for the EP El Niño events, compared with $+0.10^{\circ} \mathrm{C}$ month $^{-1}$ for the CP El Niño events (Figs. 4a,b). These results indicate a slower (faster) growth rate of the CP (EP) El Niño, corresponding to the asymmetry in the amplitudes of $\mathrm{CP}$ and EP El Niño events.

In the growth season of EP El Niño, the vertical advection terms are the most important for the SSTA tendency, with a secondary contribution from the zonal advection terms. In contrast, the meridional advection terms are almost negligible (Fig. 4a). Among the vertical advection terms, the term representing the mean upwelling and the anomalous temperature gradient $\left[-\bar{w}\left(\partial T^{\prime} / \partial z\right)\right]$, related to the so-called thermocline feedback (An and Jin 2001), has the largest contribution. This term mainly reflects the Bjerknes dynamic air-sea feedback, which is used to describe the sensitivity of the atmospheric response to the ocean forcing and vice versa. The second largest contribution is from the zonal advection term by the anomalous current and mean temperature gradient $\left[-u^{\prime}(\partial \bar{T} / \partial x)\right]$, which is associated with the so-called zonal advection feedback. In addition to these two terms, another vertical advection term, produced by the anomalous upwelling and the mean temperature gradient $\left[-w^{\prime}(\partial \bar{T} / \partial z)\right]$, also makes a positive contribution to the EP El Niño-related SSTA growth (Fig. 4a). In contrast, during the growth season of CP El Niño, the largest contributor is the zonal advection feedback, whereas the thermocline feedback is relatively weak (Fig. 4b). The possible cause of such a difference of the vertical advection between EP and CP El Niño is explained as follows: during EP El Niño development, anomalous westerlies over the westerncentral equatorial Pacific induce downwelling equatorial ocean Kelvin waves that propagate eastward to the eastern equatorial Pacific and deepen the thermocline, which may amplify the eastern Pacific SSTA due to the local upwelling/downwelling activity. These are mainly reflected by the stronger vertical advection processes, according to the recharge oscillator mechanism (Jin 1997). In contrast, as suggested by Yu and Fang (2018), such tropical recharge-discharge oscillator mechanism is not present in the growth season of CP El Niño, when 
the extratropical Pacific SST anomalies initiate CP El Niño, which subsequently develops. The vertical advection process thus becomes less important in $\mathrm{CP} \mathrm{El}$ Niño as shown in Fig. 4. The meridional advection of anomalous temperature by mean currents $\left[-\bar{v}\left(\partial T^{\prime} / \partial y\right)\right]$ provides the second largest contribution to the growth season of CP El Niño, but Kang and Kug (2002) have documented the role of this term in expanding the warm SSTA away from the equator. In addition, the surface heat flux for CP El Niño is much weaker than its counterpart for EP El Niño. Such a difference is attributed to the fact that the latent heat flux anomaly is the leading contributor to the surface heat flux in the EP, but is otherwise negligible in CP El Niño (not shown). This again supports the notion that the zonal advection feedback becomes the leading important term and dominates the CP El Niño-related SSTA warming.

The zonal advection feedback, a key part of the Bjerknes feedback (Bjerknes 1969), is closely associated with the zonal gradient of SSTA in the tropics. Despite being the second most important contributor of EP El Niño, the zonal advection feedback always plays a crucial role in the warm SSTA growth rate for both EP and CP El Niño events. We therefore applied the "robustness regression" method to identify the differences in the relationship between anomalous wind stress at every longitudinal grid and the zonal equatorial SSTA gradient in the growth season of two types of El Niño events (Fig. 5). In this analysis, all data were taken from the growth seasons (June to December) of all selected EP (CP) El Niño years, and the zonal wind stress anomalies were averaged between $5^{\circ} \mathrm{S}$ and $5^{\circ} \mathrm{N}$. According to the locations of maximum warm and cold SSTA in the equatorial Pacific, the cross-basin SSTA gradient for EP (CP) El Niño is defined by the SSTA difference between the equatorial western Pacific (WP; $120^{\circ}-160^{\circ} \mathrm{E}, 5^{\circ} \mathrm{S}-5^{\circ} \mathrm{N}$ ) and the EP (CP) box (shown in Fig. 1). The maximum significant regression coefficient over the central equatorial Pacific for EP El Niño is greater than $+93.0 \mathrm{~N} \mathrm{~m}^{-2}$ $\left({ }^{\circ} \mathrm{C} \mathrm{km}^{-1}\right)^{-1}$, but only $+47.5 \mathrm{~N} \mathrm{~m}^{-2}\left({ }^{\circ} \mathrm{C} \mathrm{km}^{-1}\right)^{-1}$ for $\mathrm{CP}$ El Niño (Fig. 5), indicating that the maximum feedback over the central equatorial Pacific during CP El Niño is half of that during EP El Niño. This ratio is similar to the ratio of the peak amplitudes of the composited $\mathrm{CP}$ and EP El Niño-related SSTA (Figs. 2 and 3). In addition, the most significant Bjerknes feedback during CP El Niño, which is the significant anomalous zonal wind stress in response to the zonal SSTA gradient, shifts westward to the western and central equatorial Pacific, particularly in the deep tropics from $140^{\circ} \mathrm{E}$ to $165^{\circ} \mathrm{W}$. Overall, the remarkable difference during the growth season of EP and $\mathrm{CP} \mathrm{El}$ Niño is the responses of the anomalous zonal wind stress to the equatorial SSTA gradient.

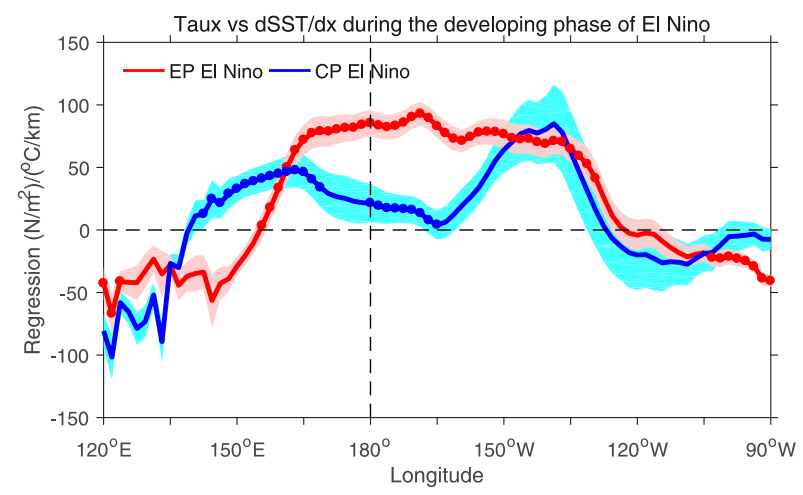

FIG. 5. Robust regression coefficients [curves; $\mathrm{N} \mathrm{m}^{-2}\left({ }^{\circ} \mathrm{C} \mathrm{km}^{-1}\right)^{-1}$ ] and their corresponding error bars (color shading) of the zonal stress wind with respect to the zonal SSTA gradient during the growth season of EP (red curve) and CP (blue curve) El Niño. The colored closed circles indicate values significant at the $90 \%$ confidence level. The robust regression coefficients between the EP and CP El Niño events are significantly different when their corresponding error bars do not overlap, and vice versa.

\section{Possible mechanism for weaker CP EI Niño amplitude}

\section{a. Observational analyses}

Figure 6 shows EP and CP El Niño composites of anomalous SST and their corresponding atmospheric circulation anomalies. During the growth season of EP El Niño, the tropical Pacific SSTA is characterized by a zonal dipole structure with warmer (colder)-thannormal signals in the eastern-central (western) tropical Pacific (Fig. 6a), accompanied by a significant dipole structure of the SLP anomalies (SLPA) with an anomalous positive (negative) center over the western (eastern) tropical Pacific (Fig. 6c). For CP El Niño, however, the associated warm SSTA center shifts westward beyond $150^{\circ} \mathrm{W}$ (Fig. 6b); accordingly, the central tropical Pacific is dominated by the negative SLPA, whose center becomes weaker and moves westward from $110^{\circ}$ to $150^{\circ} \mathrm{W}$ (Fig. 6d), in contrast to EP El Niño. Such changes in tropical SSTA and SLPA between the EP and CP El Niño events are responsible for the distinctive differences in the atmospheric responses to the zonal equatorial Pacific SSTA gradient. During the growth season of EP El Niño, low-level westerly anomalies prevail over the entire equatorial Pacific and with maximum amplitudes over the region between $150^{\circ} \mathrm{E}$ and $120^{\circ} \mathrm{W}$ (Fig. 6c). For CP El Niño, significant low-level westerly anomalies weaken and only occur over the western and central equatorial Pacific, and its westerly maximum retreats to the west of $150^{\circ} \mathrm{W}$, while easterly anomalies appear over the eastern equatorial Pacific (Fig. 6b). These low-level wind differences are generally consistent with the different responses of the anomalous zonal 


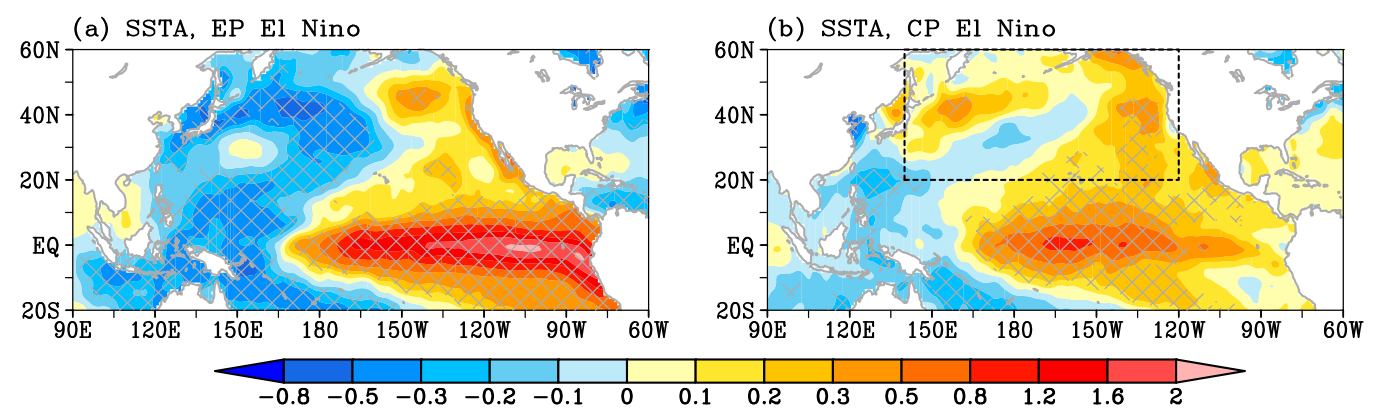

(c) SLPA \& UV850, EP El Nino
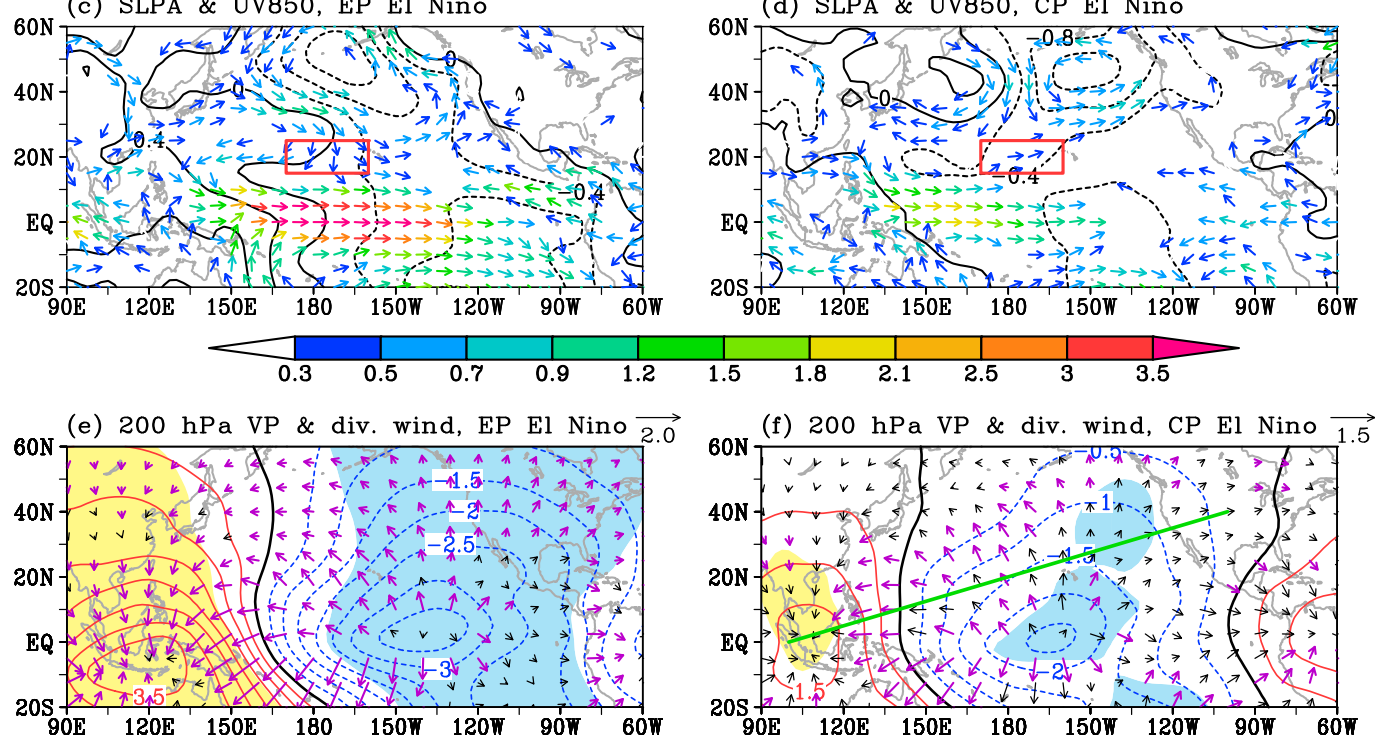

FIG. 6. Composite (a),(b) SSTA (shading; ${ }^{\circ} \mathrm{C}$ ), (c),(d) SLPA (contours; hPa) and 850-hPa wind (850UV; vector; $\mathrm{m} \mathrm{s}^{-1}$ ), and (e),(f) 200-hPa velocity potential (contours; $10^{6} \mathrm{~m}^{2} \mathrm{~s}^{-1}$ ) and divergent wind (vectors; $\mathrm{m} \mathrm{s}^{-1}$ ) during the growth season of (left) EP and right) CP El Niño events. The gray crosses in (a) and (b), colored vectors in (c) and (d), and purple vectors and shadings in (e) and (f) indicate SST, 850-hPa wind, 200-hPa divergent wind and velocity potential anomalies significant at the $90 \%$ confidence level, respectively. The dashed box shown in (b) is the key SSTA region in the North Pacific, and the red box in (c) and (d) denotes the key region for the low-level southwesterly anomalies over the subtropical North Pacific.

wind stress to the zonal SSTA gradient for EP and CP El Niño shown in Fig. 5.

Further distinct differences between EP and CP El Niño are evident in the North Pacific. It is noteworthy that SSTA associated with EP El Niño exhibit a cold SST center near $170^{\circ} \mathrm{E}$ and $40^{\circ} \mathrm{N}$ (Fig. 6a), which strongly resembles the so-called Pacific decadal oscillation (PDO) pattern, accompanied by negative SLPA over the Aleutian region (Fig. 6c). However, CP El Niño-related SSTA in the North Pacific displays a north-south dipole structure, with warming in the higher latitudes and cooling in the subtropics (Fig. 6b), which in turn are reminiscent of the North Pacific Gyre Oscillation (NPGO; Di Lorenzo et al. 2008). As the atmospheric response to the NPGO, the SLPA structure resembles the low-frequency NPO pattern revealed by Di Lorenzo et al. (2010), while significant NPO-related southwesterly $850-\mathrm{hPa}$ wind anomalies prevail over the subtropical North Pacific $\left(170^{\circ} \mathrm{E}-160^{\circ} \mathrm{W}, 15^{\circ}-25^{\circ} \mathrm{N}\right)$ during the growth season of CP El Niño (Fig. 6d). This is remarkably different from the situation during EP El Niño, where the subtropical region is controlled by the anomalous northwesterly wind in the low-level atmosphere (Fig. 6c). Yu et al. (2010) first linked the CP El Niño events to the subtropical process, and $\mathrm{Yu}$ and Kim (2011) subsequently raised the linkage of the NPO to the growth season of CP El Niño. Statistical correlation and partial correlation tests were conducted to examine the relationships among the $10-\mathrm{m}$ zonal wind anomalies over the central-western equatorial Pacific $\left(140^{\circ} \mathrm{E}-170^{\circ} \mathrm{W}, 5^{\circ} \mathrm{S}-5^{\circ} \mathrm{N}\right)$, the equatorial central Pacific SSTA index over the CP box (shown in Fig. 1b), and the NPGO index defined by Di Lorenzo et al. (2008). The results indicate that the association between surface 
zonal wind and CP El Niño becomes weaker (the correlation coefficient declines from +0.75 to +0.69 ) when the NPGO influence is removed, highlighting the modulation effect of the NPGO on CP El Niño. Also, the linkage between the NPGO index and surface zonal wind weakens dramatically from +0.38 to +0.21 if the $\mathrm{CP}$ index is excluded, which suggests that modulation of the NPGO-like SSTA on the surface equatorial zonal wind does exist but tends to emerge in the CP El Niño years. These results suggest that the surface zonal wind over the central-western equatorial Pacific acts partly as a response to the CP El Niño-like SSTA warming but is also closely associated with NPGO-like SST anomalies over the North Pacific.

Wang et al. (2019) highlighted the important roles of the subtropical North Pacific southwesterly wind anomalies in the occurrence of CP El Niño, and $\mathrm{Yu}$ and Fang (2018) further explained the increase of El Niño complexity and asymmetry by the seasonal footprinting mechanism. During the growth season of CP El Niño, the warm SST anomalies extending from the subtropical northeastern Pacific into the equatorial central Pacific, which are similar to the Pacific meridional mode (Chiang and Vimont 2004), are more closely related to the low-level southwesterly anomalies over the subtropical northeastern Pacific (Figs. 6b,d), which oppose the climatological near-surface northeasterly trade winds. Thus, the total wind speed and associated surface evaporation are reduced. Through the WES feedback, the anomalous warm SST can enhance and maintain itself in the subtropical northeastern Pacific and thus spread southwestward to the central equatorial Pacific, subsequently causing the westward extension of the negative SLPA over the tropics and ultimately triggering a CP El Niño. Therefore, the anomalous low-level southwesterlies over the subtropical North Pacific effectively act as a conduit for extratropical air-sea interaction, influencing the onset of CP El Niño.

We also examined the large-scale 200-hPa divergent winds over the Pacific associated with $\mathrm{EP}$ and $\mathrm{CP} \mathrm{El}$ Niño (Figs. 6e,f). During the growth season of EP El Niño, the anomalous upper-level convergence center is positioned over the Maritime Continent while the significant divergence anomalies are concentrated near the central-eastern tropical Pacific, presenting a more zonally overturning circulation (i.e., Walker circulation) (Fig. 6e). This pattern of divergent circulation is collocated with the EP El Niño-related zonal SSTA pattern. For CP El Niño events, however, the anomalous upperlevel divergences and ascending branch in the tropics are located over the central tropical Pacific, along with the two anomalous convergence centers to the west of the Maritime Continent and South America (Fig. 6f). In

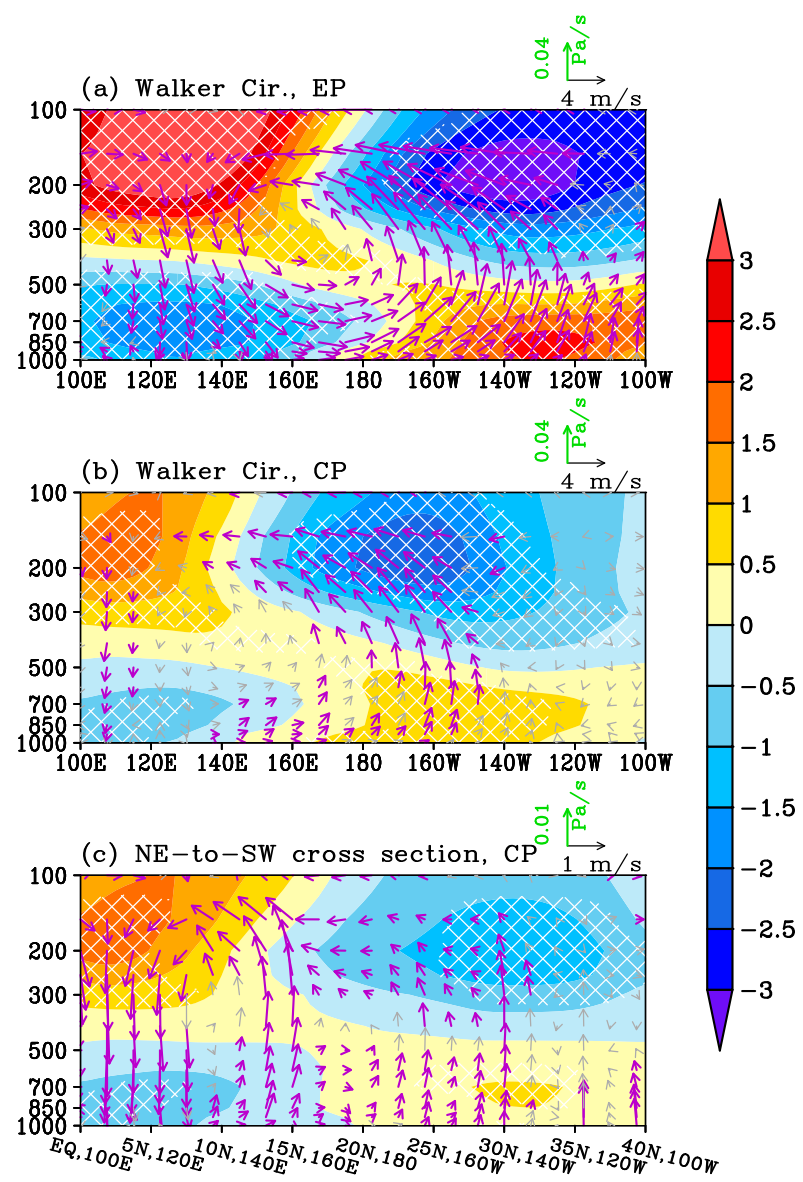

FIG. 7. The anomalous Walker circulation (vectors; zonal divergent wind and vertical pressure velocity; see scale at the top right of each panel) and velocity potential composites (shading; $10^{6} \mathrm{~m}^{2} \mathrm{~s}^{-1}$ ) averaged over $2.5^{\circ} \mathrm{S}-2.5^{\circ} \mathrm{N}$ during the growth season of (a) EP and (b) CP El Niño events. The vertical pressure velocity is multiplied by a factor of -200 for clarity. Purple vectors and white crosses indicate divergent winds and velocity potential anomalies significant at the $90 \%$ confidence level, respectively. (c) As in (a), but for the northeast-southwest cross section along the green sloped line over the Pacific shown in Fig. $6 f$.

the extratropics, the anomalous large-scale convergence in the upper troposphere is significant over the subtropical North and South Pacific (Fig. 6f). These results imply that, besides the Walker circulation over the tropics, a more meridionally oriented overturning circulation may also be an essential feature during the growth season of CP El Niño, as indicated by previous results (Yu et al. 2010, 2012a; Xu et al. 2017b).

To better describe the differences in atmospheric circulation between EP and CP El Niño events, vertical cross sections of the anomalous divergent wind circulation and velocity potential near the equator are shown in Figs. $7 \mathrm{a}$ and $7 \mathrm{~b}$. The anomalous Walker circulation over the equatorial Pacific during EP El Niño exhibits a clear single-cell structure in the troposphere, with its ascending 
branch over a broad longitudinal band east of the date line and the descending branch over the western equatorial Pacific between $110^{\circ}$ and $150^{\circ} \mathrm{E}$ (Fig. 7a). The maximum anomalous ascending (descending) center coincides with significant low-level convergence (divergence) and upper-level divergence (convergence) anomalies, in accordance with the underlying equatorial Pacific SSTA. Similar to EP El Niño, the associated upper- and lower-level convergence and divergence anomalies during the growth season of CP El Niño are mirror images of each other, indicating the baroclinic vertical structure of the associated velocity potential anomalies over the equatorial Pacific. However, their magnitude is relatively weak and the pattern is shifted westward compared to EP El Niño (Fig. 7b). This displacement indicates that the anomalous CP El Niñorelated Walker circulation, which is distinguished by the maximum ascent being positioned over the equatorial central Pacific between $160^{\circ} \mathrm{E}$ and $150^{\circ} \mathrm{W}$ and the main descent over the western equatorial Pacific, is also displaced westward in accordance with the underlying equatorial Pacific SSTA, in contrast to the counterpart of EP El Niño. Yu et al. (2012a) pointed out that the NPO-related atmospheric forcing could strengthen the Hadley circulation by increasing tropical Pacific SST variability, leading to the increasing occurrence of $\mathrm{CP}$ El Niño. Our analysis also shows that the CP El Niñorelated overturning circulation exhibits more meridionally oriented properties. To further verify this hypothesis, the vertical northeast-southwest cross section of the anomalous divergent wind circulation from the western equatorial Pacific to the subtropical northeastern Pacific (marked by the green solid line in Fig. 6f) is shown in Fig. 7c. During the growth season of CP El Niño, a single-cell structure is still evident in the troposphere, with a remarkable sinking branch over the tropical western Pacific and a significant rising branch over the broadly extratropical North Pacific, and the anomalous velocity potential centers are comparable to those of the EP El Niño despite the fact that they are relatively weakened (Fig. 7c). However, the anomalous low-level convergence and upper-level divergence, corresponding to the ascending motion anomalies, are found to cover a broad region in the subtropical northeastern Pacific (Fig. 7c). Thus, the anomalous low-level southwesterly wind, which can spread the warm SSTA to the central equatorial Pacific via the WES feedback, prevails on the western side of the low-level convergence. Comparing Figs. $7 \mathrm{~b}$ and $7 \mathrm{c}$, it can be seen that a local meridional overturning cell is located over the eastern Pacific with its ascending (descending) branch over the extratropical northeastern Pacific (eastern equatorial Pacific) during the growth season of $\mathrm{CP} \mathrm{El}$
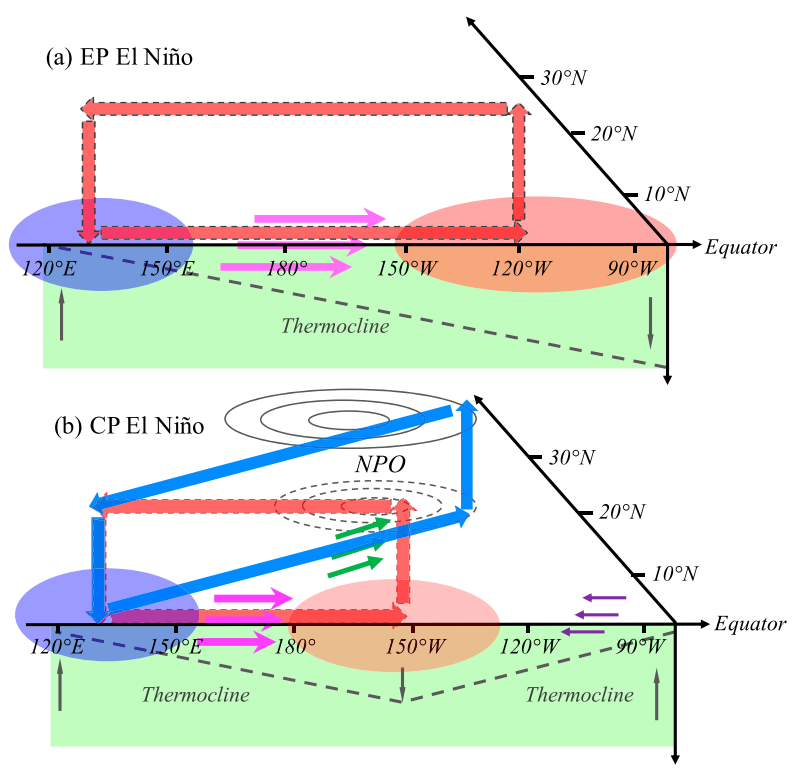

FIG. 8. Schematic diagram illustrating the main Pacific atmospheric overturning circulation, low-level wind, and thermocline anomalies for the growth season of (a) EP and (b) CP El Niño events.

Niño. These results demonstrate that the anomalous local Hadley circulation over the eastern tropical Pacific is also one of the most important factors for the growth season of CP El Niño, consistent with the conclusions of Yu et al. (2010).

The key differences between the growth season of EP and CP El Niño events are summarized in Fig. 8. The EP El Niño-related SSTA exhibits a zonal dipole pattern with the warmer (colder)-than-normal SSTA center in the eastern-central (western) tropical Pacific, corresponding to a basinwide zonally tilted thermocline with shoaling in the western Pacific and deepening in the eastern Pacific. The zonal equatorial SSTA gradient is accompanied by the remarkably anomalous surface westerlies near the date line over the central equatorial Pacific; accordingly, the atmospheric overturning circulation is zonally in phase with the underlying SSTA, with the maximum ascending anomalies over the eastern equatorial Pacific and descending anomalies over the western equatorial Pacific (Fig. 8a). In contrast, during the growth season of CP El Niño, the SSTA and the associated atmospheric overturning circulation anomalies differ markedly from their EP El Niño counterparts. The warming CP El Niño-related SSTA center is located in the central equatorial Pacific, accompanied by the anomalous surface westerlies over the western equatorial Pacific and the anomalous surface easterlies over the eastern equatorial Pacific (Fig. 8b), which can force a V-shaped thermocline anomaly in the equator, with deeper anomalies in the central Pacific but 


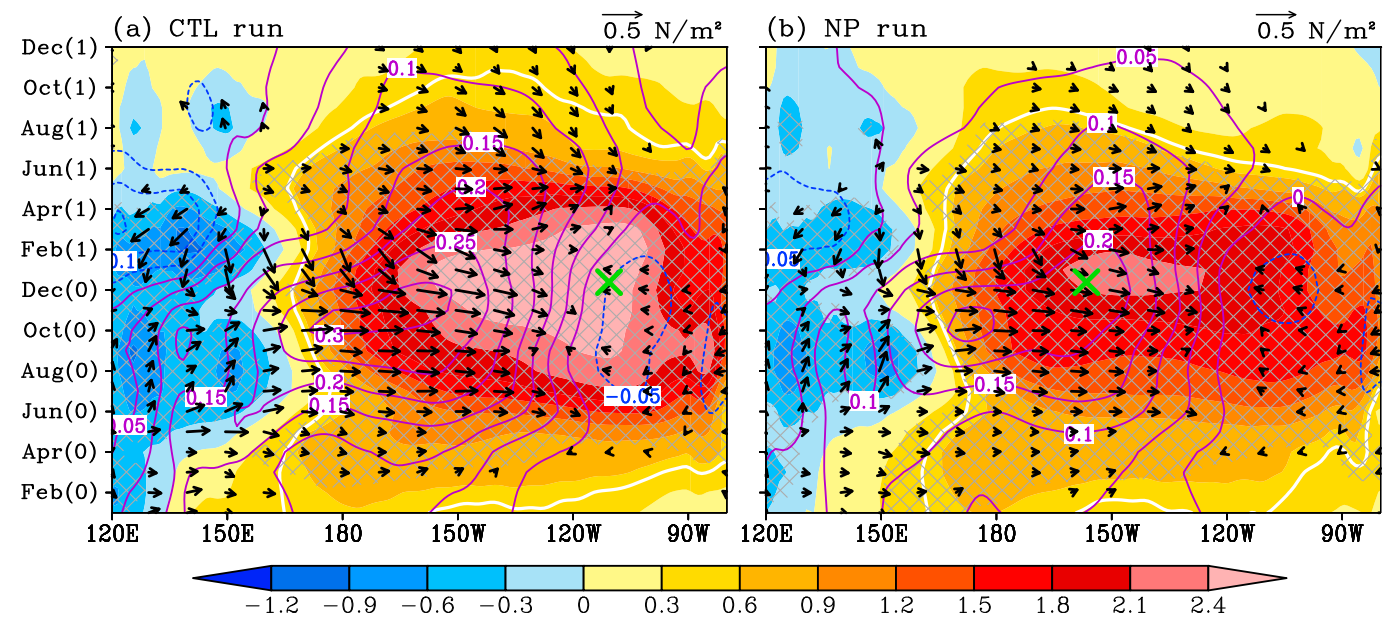

FIG. 9. Time-longitude cross section of composite SST (shading; ${ }^{\circ} \mathrm{C}$ ), wind stress (vectors; units of magnitude of horizontal scale arrow: $\mathrm{N} \mathrm{m}^{-2}$ ), and zonal wind stress (contours; $\mathrm{N} \mathrm{m}^{-2}$ ) anomalies at the equator (averaged from $5^{\circ} \mathrm{S}$ to $5^{\circ} \mathrm{N}$ ) for the El Niño events simulated by the (a) CTL and (b) NP runs, where (0) indicates the El Niño year and (1) represents the following year. White contours indicate the regions with the SST anomalies greater than $+0.5^{\circ} \mathrm{C}$. Green crosses mark the longitudes of the maximum SSTA during the peak of El Niño events, which were spatially smoothed using a three-point running mean. Gray crosses and black vectors denote SST and wind stress anomalies that are statistically significant at the $90 \%$ confidence level.

shallower anomalies near both lateral boundaries $(\mathrm{Xu}$ et al. 2017a). Compared with EP El Niño, the anomalous surface westerlies during CP El Niño are weakened and shift westward to the west of the date line, leading to the westward displacement of the Walker circulation in accordance with the underlying zonal equatorial Pacific SSTA. It is evident that the biggest difference between EP and CP El Niño during their respective growth season is the significant tropical-extratropical interaction for CP El Niño, consistent with the results revealed by Kim et al. (2012). The anomalous surface southwesterly over the subtropical North Pacific, which is closely related to the NPO-like atmospheric response induced by the North Pacific SSTA, can spread the warming SSTA to the central equatorial Pacific via the WES feedback processes, finally triggering CP El Niño (Fig. 8b). Therefore, the anomalous southwesterly wind is an effective conduit for the extratropical air-sea influence on the occurrence of CP El Niño. These results suggest that, besides the Walker circulation, a more meridionally oriented atmospheric overturning circulation over the tropical-subtropical Pacific region plays an important role in the growth season of CP El Niño.

\section{b. Numerical experiments}

Thus far we have used observational data to illustrate the potential association of North Pacific SST anomalies with the CP El Niño and its weak amplitude. To further investigate how these SSTA modulates El Niño amplitudes, we have conducted a series of sensitivity experiments using CESM. In the control (CTL) run, the global ocean and atmosphere are fully coupled except in the North Pacific $\left(140^{\circ} \mathrm{E}-120^{\circ} \mathrm{W}, 20^{\circ}-60^{\circ} \mathrm{N}\right.$, marked by the dashed box in Fig. 6b) where the North Pacific SST is nudged toward seasonally varying climatological SST, obtained by averaging the last 200 years of the 1200 -yr fully coupled control simulation of CESM. The second experiment, the NP run, is the same as the CTL run except that the North Pacific SST is nudged toward monthly NPGO-like SSTA during the developing year of CP El Niño, superimposed onto the seasonally varying CESM climatological SST (Fig. 6b). Both runs were integrated for 100 years, and results for the last 50 years were analyzed. Note that we found 8 and $12 \mathrm{El}$ Niño events in the 50-yr simulations of both CTL and NP runs. Therefore, the differences between the NP and CTL runs represent the global climate anomalies induced purely by NPGO-like SSTA in the North Pacific.

Figure 9 depicts the evolutions of the composite equatorial SSTA, wind stress anomalies, and zonal wind stress anomalies averaged from $5^{\circ} \mathrm{S}$ to $5^{\circ} \mathrm{N}$ for the El Niño events in the CTL and NP runs. In the CTL experiment, the anomalous equatorial SST and wind stress responses are very similar to the observed air-sea coupled interaction associated with EP El Niño, albeit with different magnitudes and center locations (Fig. 9a). The most remarkable zonal dipole patterns of the El Niñorelated SSTA are established over the equatorial Pacific during boreal winter. The significant anomalous warm SST center is mainly confined to the central-eastern 
equatorial Pacific, with maximum warm SSTA located at $110^{\circ} \mathrm{W}$. Westerly wind stress anomalies appear over the western equatorial Pacific in April (0), before they gradually strengthen and extend eastward to the west of $120^{\circ} \mathrm{W}$ over the next few months (Fig. 9a). During the mature stage of EP El Niño in the CTL run, the anomalous westerly wind stress center, with a maximum amplitude of $+0.3^{\circ} \mathrm{N} \mathrm{m}^{-2}$, is located over the central equatorial Pacific, slightly east of the date line.

In the NP experiment, the anomalous equatorial Pacific SST and wind stress responses, including their magnitudes and locations, are quite different from those reproduced in the CTL run. The warm El Niño-related SSTA center shifts westward to the central equatorial Pacific, with the location of strongest signals shifted westward from $110^{\circ}$ to $160^{\circ} \mathrm{W}$ (Fig. 9b) - a typical spatial feature of CP El Niño. Furthermore, the intensity of El Niño events $\left(+2.1^{\circ} \mathrm{C}\right)$ simulated in the NP run is weaker than that $\left(+2.8^{\circ} \mathrm{C}\right)$ of the CTL run, causing the attenuated zonal SSTA gradient in the equatorial Pacific. The CESM results further indicate that there exists pronounced amplitude asymmetry between the two types of El Niño. Similar to the results from the CTL run, the westerly wind stress anomalies also occur over the western equatorial Pacific in the early spring. Subsequently, they gradually develop and extend eastward to the central Pacific, along with the prominently equatorial easterly anomalies over the eastern equatorial Pacific. The biggest difference between the two runs is that the anomalous zonal wind stress center, with a maximum amplitude of $+0.25 \mathrm{~N} \mathrm{~m}^{-2}$, is primarily located west of the date line in the NP experiment (Fig. 9b). Therefore, the results from the NP run, which illustrate the responses to the NPGO-like SSTA in the North Pacific, are similar to the observed equatorial Pacific air-sea interaction composites for CP El Niño. Meanwhile, all the El Niño events reproduced by both CTL and NP runs exhibit a peak phase in boreal winter. The life cycle of El Niño in the NP run is slightly shorter than that in the CTL run, and the El Niño intensity simulated in the NP run is weaker than that in the CTL run (Fig. 9). Comparison between CTL and NP runs reveals that the El Niño-related air-sea coupling evolutions in the NP experiment are much weaker than their counterparts in CTL, suggesting that NPGO-like SSTA in the North Pacific become more effective in triggering CP El Niño via the tropical-extratropical atmospheric interactions. Additionally, the anomalous westerly wind stress is an important factor contributing to the amplitude of the two types of El Niño. The responses of the anomalous westerly wind stress to the NPGO-like SSTA in the North Pacific are weakened due to the westward extension of the negative SLPA
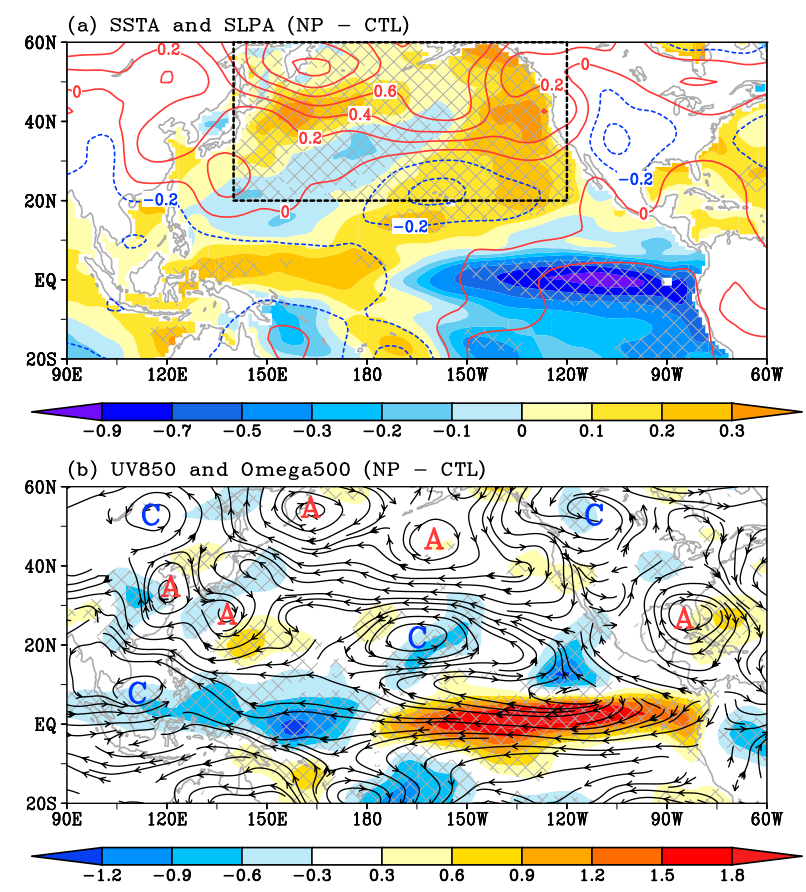

FIG. 10. Difference of composite (a) SSTA (shading; ${ }^{\circ} \mathrm{C}$ ) and SLPA (contours; hPa), and (b) 850-hPa wind anomalies (streamlines) and 500-hPa vertical velocity (shading; $10^{-2} \mathrm{~Pa} \mathrm{~s}^{-1}$ ) during the growth season of El Niño events between the NP and CTL runs. Gray crosses in (a) and (b) indicate SSTA and vertical velocity anomalies significant at the $90 \%$ confidence level, respectively. In (b), the red (blue) letter A (C) denotes the center of the anomalous anticyclone (cyclone) at $850 \mathrm{hPa}$.

over the deep tropics, resulting in attenuation of the $\mathrm{CP}$ El Niño amplitude.

To further investigate the physical mechanism behind modulation of the CP El Niño amplitude by the North Pacific SSTA, Fig. 10 depicts the differences in composite Pacific SSTA, SLPA, wind anomalies at $850 \mathrm{hPa}$ and vertical velocity anomalies at $500 \mathrm{hPa}$ during the growth season of El Niño, computed by subtracting the CTL from the NP run results. In response to the North Pacific SSTA (see Fig. 6b), North Pacific atmospheric circulation anomalies are characterized by a SLPA meridional dipole, with the positive (negative) pressure anomalies in the higher-latitude (subtropical) Pacific (Fig. 10a). Associated with this is the anomalous lowlevel anticyclone (cyclone) over the higher-latitude (subtropical) North Pacific (Fig. 10b). This circulation feature is reminiscent of the so-called NPO pattern, which is capable of forcing the subtropical SSTA in the northeastern Pacific (Yu and Giese 2013). The anomalous low-level southwesterlies caused by the cyclonic circulation over the subtropical North Pacific greatly resemble those for the CP El Niño events in the observations. The anomalous low-level southwesterlies can sustain the subtropical warm SSTA and cause them to 
spread toward the central equatorial Pacific via the WES feedback. This result again suggests that the low-level southwesterly wind anomalies act as an effective conduit for the extratropical NPO forcing influence on CP El Niño. In the deep tropics, the SSTA and SLPA responses exhibit a La Niña-like pattern, where weakened SSTA and positive SLPA are located over the eastern equatorial Pacific, along with strengthened SSTA and negative SLPA over the western equatorial Pacific (Fig. 10a). It is evident that marked anomalous easterlies prevail over the equatorial Pacific (Fig. 10b). These results suggest that $\mathrm{CP}$ El Niño tends to occur more frequently, and its associated amplitude is decreased, under the extratropical atmospheric forcing by the NPGO-like SSTA. Additionally, the 500-hPa vertical velocity anomalies exhibit a dipole pattern with remarkable descending (ascending) anomalies over the eastern (western) equatorial Pacific, indicating a weakening of El Niño-related Walker circulation anomalies, and hence the El Niño amplitude itself. The significant ascending motion anomalies are obvious over the subtropical northeastern Pacific, suggesting there exists an accelerated meridionally oriented atmospheric overturning circulation over the tropical-subtropical region forced by the NPGO-like SSTA in the North Pacific. Subsequently, the related low-level southwesterly anomalies are conducive to the occurrence of $\mathrm{CP} \mathrm{El}$ Niño via the WES feedback.

\section{Summary and discussion}

The asymmetry between EP and CP El Niño amplitudes and the possible role of North Pacific SSTA have been investigated, based on analyses of observations and numerical model experiments. During the El Niño growth season, the amplitude of CP El Niño events is about half that of EP El Niño events. However, CP El Niño develops slower but decays faster than EP El Niño, meaning that CP El Niño events have a shorter lifespan. This amplitude asymmetry is attributed to the weaker anomalous zonal wind stress response to equatorial Pacific SSTA gradient in the growing phase of CP El Niño. Mixed layer heat budget analysis reveals that SSTA warming in EP El Niño events can mainly be attributed to the thermocline feedback, with the zonal advection feedback playing a secondary role. In contrast, temperature advection is the major contribution to SSTA warming in CP El Niño events.

Our results confirm the role of North Pacific SSTA in attenuating the $\mathrm{CP}$ El Niño amplitude. In contrast to positive PDO-like SSTA for the EP El Niño development, a NPGO-like SSTA pattern, with warming in the higher latitudes and cooling in the subtropics, can be observed in the North Pacific during the growing phase of CP El Niño events, and a meridionally oriented atmospheric overturning circulation is more pronounced in the tropical-to-subtropical Pacific, consistent with previous results (Yu et al. 2010; Xu et al. 2013, 2017b). We propose a hypothesis that the NPGO-like SSTA can induce NPO-like atmospheric circulation over the North Pacific with anomalous low-level southwesterlies prevailing over the subtropical North Pacific. The anomalous southwesterly winds effectively act as a conduit between the extratropical atmosphere/ocean and El Niño variability. They have the opposite direction to the climatological near-surface northeasterly trade winds, and thus reducing the total wind speed and associated surface evaporation. As a result, the anomalous southwesterly winds enhance and maintain subtropical northeastern Pacific SSTA warming through the WES feedback, driving a southwestward spreading warming SSTA to the central equatorial Pacific, and finally triggering a CP El Niño. The related air-sea processes enhance the tropical-extratropical linkage and result in a westward extension of negative SLPA in the tropics, subsequently weakening the atmospheric response to the zonal equatorial Pacific SSTA gradient, which ultimately attenuates the CP El Niño amplitude.

This hypothesis was validated in numerical experiments using CESM. In these experiments driven by various North Pacific SST patterns, the simulated equatorial Pacific SSTA, wind stress, and their coupling compare well with the observed air-sea interaction during EP and CP El Niño events. Forced by NPGOlike SSTA in the North Pacific, CP El Niño events are more frequent in the equatorial Pacific. Furthermore, their associated amplitudes are remarkably weakened. These results strongly suggest that North Pacific NPGOlike SSTA plays a fundamental role in modulating the CP El Niño amplitude.

Huang and Wang (2001) revealed that the communication between the subtropical gyre interior and the tropics is one of the important oceanic channels for tropical-extratropical interactions. The interior communication is closely related to the ENSO cycle and plays a vital role in the dynamic balance of the equatorial thermocline. In this work, we have documented the influence of North Pacific SSTA on CP El Niño and its amplitude. However, the physical mechanism of such communication (i.e., whether the pathway is primarily atmospheric or oceanic in nature) remains unknown. Further observational analyses and model experiments need to be conducted, in order to elucidate the relative roles of the atmospheric and oceanic pathways in the North Pacific SSTA modulation of CP El Niño amplitude. 
Acknowledgments. This work is jointly supported by the National Key R\&D Program of China (2019YFA0606701), the Strategic Priority Research Program of Chinese Academy of Sciences (XDB420000000), the Research Program of Southern Marine Science and Engineering Guangdong Laboratory (Guangzhou) (GML2019ZD0306), the National Natural Science Foundation of China (41776023, 91958202, 41731173, 41521005, 91858203, 41676015), the Youth Innovation Promotion Association CAS (2020340), the Rising Star Foundation of the SCSIO (NHXX2018WL0201), the Innovation Academy of South China Sea Ecology and Environmental Engineering, CAS (ISEE2018PY06), the Chinese University Direct Grant (4053283), and the MEL Visiting Fellowship. The numerical simulation is supported by the High Performance Computing Division and HPC managers of Wei Zhou and Dandan Sui in the SCSIO.

\section{REFERENCES}

An, S.-I., and F.-F. Jin, 2001: Collective role of thermocline and zonal advective feedbacks in the ENSO mode. J. Climate, 14, 3421-3432, https://doi.org/10.1175/1520-0442(2001)014<3421: CROTAZ $>2.0 . \mathrm{CO} ; 2$.

, and - 2004: Nonlinearity and asymmetry of ENSO. J. Climate, 17, 2399-2412, https://doi.org/10.1175/15200442(2004)017<2399:NAAOE > 2.0.CO;2.

Ashok, K., S. K. Behera, S. A. Rao, H. Weng, and T. Yamagata, 2007: El Niño Modoki and its possible teleconnection. J. Geophys. Res., 112, C11007, https://doi.org/10.1029/2006JC003798.

_- M. Shamal, A. K. Sahai, and P. Swapna, 2017: Nonlinearities in the evolutional distinctions between El Niño and La Niña types. J. Geophys. Res. Oceans, 122, 9649-9662, https:// doi.org/10.1002/2017JC013129.

Balmaseda, M. A., K. Mogensen, and A. T. Weaver, 2013: Evaluation of the ECMWF ocean reanalysis system ORAS4. Quart. J. Roy. Meteor. Soc., 139, 1132-1161, https://doi.org/ 10.1002/qj.2063.

Beyene, M. T., and S. Jain, 2018: North American wintertime temperature anomalies: The role of El Niño diversity and differential teleconnections. Climate Dyn., 50, 4365-4377, https://doi.org/10.1007/s00382-017-3880-x.

Bjerknes, J., 1969: Atmospheric teleconnections from the equatorial Pacific. Mon. Wea. Rev., 97, 163-172, https://doi.org/ 10.1175/1520-0493(1969)097<0163:ATFTEP $>2.3 . C O ; 2$.

Capotondi, A., and Coauthors, 2015: Understanding ENSO diversity. Bull. Amer. Meteor. Soc., 96, 921-938, https://doi.org/ 10.1175/BAMS-D-13-00117.1.

Carton, J. A., and B. S. Giese, 2008: A reanalysis of ocean climate using Simple Ocean Data Assimilation (SODA). Mon. Wea. Rev., 136, 2999-3017, https://doi.org/10.1175/2007MWR1978.1.

Chen, D., and Coauthors, 2015: Strong influence of westerly wind bursts on El Niño diversity. Nat. Geosci., 8, 339-345, https:// doi.org/10.1038/ngeo2399.

Chen, X., and J. M. Wallace, 2015: ENSO-like variability: 19002013. J. Climate, 28, 9623-9641, https://doi.org/10.1175/JCLID-15-0322.1.

Chiang, J. C. H., and D. J. Vimont, 2004: Analogous Pacific and Atlantic meridional modes of tropical atmosphere-ocean variability. J. Climate, 17, 4143-4158, https://doi.org/10.1175/ JCLI4953.1.

Chung, P.-H., and T. Li, 2013: Interdecadal relationship between the mean state and El Niño types. J. Climate, 26, 361-379, https://doi.org/10.1175/JCLI-D-12-00106.1.

Di Lorenzo, E., and Coauthors, 2008: North Pacific Gyre Oscillation links ocean climate and ecosystem change. Geophys. Res. Lett., 35, L08607, https://doi.org/10.1029/2007GL032838.

— K. M. Cobb, J. C. Furtado, N. Schneider, B. T. Anderson, A. Bracco, M. A. Alexander, and D. J. Vimont, 2010: Central Pacific El Niño and decadal climate change in the North Pacific Ocean. Nat. Geosci., 3, 762-765, https://doi.org/10.1038/ngeo984.

—, G. Liguori, N. Schneider, J. C. Furtado, B. T. Anderson, and M. A. Alexander, 2015: ENSO and meridional modes: A null hypothesis for Pacific climate variability. Geophys. Res. Lett. 42, 9440-9448, https://doi.org/10.1002/2015GL066281.

Feng, J., and J. Li, 2011: Influence of El Niño Modoki on spring rainfall over south China. J. Geophys. Res., 116, D13102, https://doi.org/10.1029/2010JD015160.

_ , L. Wang, W. Chen, S. K. Fong, and K. C. Leong, 2010: Different impacts of two types of Pacific Ocean warming on Southeast Asian rainfall during boreal winter. J. Geophys. Res., 115, D24122, https://doi.org/10.1029/2010JD014761.

_, W. Chen, C.-Y. Tam, and W. Zhou, 2011: Different impacts of El Niño and El Niño Modoki on China rainfall in the decaying phases. Int. J. Climatol., 31, 2091-2101, https://doi.org/ $10.1002 /$ joc. 2217 .

,$--\frac{1}{-}$, and Y. Li, 2017: Asymmetry of the winter extra-tropical teleconnections in the Northern Hemisphere associated with two types of ENSO. Climate Dyn., 48, 2135-2151, https:// doi.org/10.1007/s00382-016-3196-2.

Gu, D., and S. G. H. Philander, 1997: Interdecadal climate fluctuations that depend on exchanges between the tropics and extratropics. Science, 275, 805-807, https://doi.org/10.1126/ science.275.5301.805.

He, Z., W. Wang, R. Wu, I.-S. Kang, C. He, X. Li, K. Xu, and S. Chen, 2020: Change in coherence of summer rainfall variability over the western Pacific around the early 2000s: ENSO influence. J. Climate, 33, 1105-1119, https://doi.org/10.1175/ JCLI-D-19-0150.1.

Holland, P. W., and R. E. Welsch, 1977: Robust regression using iteratively reweighted least-squares. Commun. Stat. Theory Methods, 6, 813-827, https://doi.org/10.1080/03610927708827533.

$\mathrm{Hu}, \mathrm{S}$., and A. V. Fedorov, 2018: Cross-equatorial winds control El Niño diversity and change. Nat. Climate Change, 8, 798-802, https://doi.org/10.1038/s41558-018-0248-0.

Huang, R. X., and Q. Wang, 2001: Interior communication from the subtropical to the tropical oceans. J. Phys. Oceanogr., 31 3538-3550, https://doi.org/10.1175/1520-0485(2001)031<3538: ICFTST $>2.0 . \mathrm{CO} ; 2$.

Hunke, E. C., and W. H. Lipscomb, 2010: CICE: The Los Alamos Sea Ice Model documentation and software user's manual, version 4.1. Doc. LA-CC-06-012, 76 pp., https://csdms. colorado.edu/w/images/CICE_documentation_and_software_ user's_manual.pdf.

Hurrell, J. W., and Coauthors, 2013: The Community Earth System Model: A framework for collaborative research. Bull. Amer. Meteor. Soc., 94, 1339-1360, https://doi.org/10.1175/BAMS-D12-00121.1.

Jin, F.-F., 1997: An equatorial ocean recharge paradigm for ENSO. Part I: Conceptual model. J. Atmos. Sci., 54, 811-829, https://doi.org/10.1175/1520-0469(1997)054<0811:AEORPF> 2.0.CO;2. 
Kalnay, E., and Coauthors, 1996: The NCEP/NCAR 40-Year Reanalysis Project. Bull. Amer. Meteor. Soc., 77, 437-471, https://doi.org/10.1175/1520-0477(1996)077<0437:TNYRP> 2.0.CO;2.

Kang, I.-S., and J.-S. Kug, 2002: El Niño and La Niña sea surface temperature anomalies: Asymmetry characteristics associated with their wind stress anomalies. J. Geophys. Res., 107, 4372, https://doi.org/10.1029/2001JD000393.

- H. H. No, and F. Kucharski, 2014: ENSO amplitude modulation associated with the mean SST changes in the tropical central Pacific induced by Atlantic multidecadal oscillation. J. Climate, 27, 7911-7920, https://doi.org/10.1175/JCLI-D-1400018.1.

Kao, H.-Y., and J.-Y. Yu, 2009: Contrasting eastern-Pacific and central-Pacific types of ENSO. J. Climate, 22, 615-632, https:// doi.org/10.1175/2008JCLI2309.1.

Kim, S. T., J.-Y. Yu, A. Kumar, and H. Wang, 2012: Examination of the two types of ENSO in the NCEP CFS model and its extratropical associations. Mon. Wea. Rev., 140, 1908-1923, https://doi.org/10.1175/MWR-D-11-00300.1.

Kug, J.-S., F.-F. Jin, and S.-I. An, 2009: Two types of El Niño events: Cold tongue El Niño and warm pool El Niño. J. Climate, 22, 1499-1515, https://doi.org/10.1175/2008JCLI2624.1.

Kumar, K. K., B. Rajagopalan, M. Hoerling, G. Bates, and M. Cane, 2006: Unraveling the mystery of Indian monsoon failure during El Niño. Science, 314, 115-119, https://doi.org/ 10.1126/science. 1131152.

Larkin, N. K., and D. E. Harrison, 2005: On the definition of El Niño and associated seasonal average U.S. weather anomalies. Geophys. Res. Lett., 32, L13705, https://doi.org/10.1029/ 2005GL022738.

Lee, T., and M. J. McPhaden, 2010: Increasing intensity of El Niño in the central-equatorial Pacific. Geophys. Res. Lett., 37 L14603, https://doi.org/10.1029/2010GL044007.

Li, T., Y. Zhang, E. Lu, and D. Wang, 2002: Relative role of dynamic and thermodynamic processes in the development of the Indian Ocean dipole: An OGCM diagnosis. Geophys. Res. Lett., 29, 2110, https://doi.org/10.1029/2002GL015789.

McPhaden, M. J., S. E. Zebiak, and M. H. Glantz, 2006: ENSO as an integrating concept in Earth science. Science, 314, 17401745, https://doi.org/10.1126/science.1132588.

_, T. Lee, and D. McClurg, 2011: El Niño and its relationship to changing background conditions in the tropical Pacific Ocean. Geophys. Res. Lett., 38, L15709, https://doi.org/10.1029/ 2011 GL048275.

Neale, R. B., J. Richter, S. Park, P. H. Lauritzen, S. J. Vavrus, P. J. Rasch, and M. Zhang, 2013: The mean climate of the Community Atmosphere Model (CAM4) in forced SST and fully coupled experiments. J. Climate, 26, 5150-5168, https:// doi.org/10.1175/JCLI-D-12-00236.1.

Newman, M., S.-I. Shin, and M. A. Alexander, 2011: Natural variation in ENSO flavors. Geophys. Res. Lett., 38, L14705, https://doi.org/10.1029/2011GL047658.

Oleson, K. W., and Coauthors, 2010: Technical description of version 4.0 of the Community Land Model (CLM). NCAR Tech. Note NCAR/TN-478+STR, 257 pp., https://doi.org/ 10.5065/D6FB50WZ.

Rasmusson, E. M., and T. H. Carpenter, 1982: Variations in tropical sea surface temperature and surface wind fields associated with the Southern Oscillation/El Niño. Mon. Wea. Rev., 110,354-384, https:// doi.org/10.1175/1520-0493(1982)110<0354:VITSST>2.0.CO;2.

Rayner, N. A., D. E. Parker, E. B. Horton, C. K. Folland, L. V. Alexander, D. P. Rowell, E. C. Kent, and A. Kaplan, 2003
Global analyses of sea surface temperature, sea ice, and night marine air temperature since the late nineteenth century. J. Geophys. Res., 108, 4407, https://doi.org/10.1029/2002JD002670.

Ren, H.-L., and F.-F. Jin, 2011: Niño indices for two types of ENSO. Geophys. Res. Lett., 38, L04704, https://doi.org/ 10.1029/2010GL046031.

$\longrightarrow$, and - 2013: Recharge oscillator mechanisms in two types of ENSO. J. Climate, 26, 6506-6523, https://doi.org/10.1175/ JCLI-D-12-00601.1.

Smith, R., and Coauthors, 2010: The Parallel Ocean Program (POP) reference manual: Ocean component of the Community Climate System Model (CCSM) and Community Earth System Model (CESM). 141 pp., http://www.cesm.ucar.edu/models/ cesm1.0/pop2/doc/sci/POPRefManual.pdf.

Sohn, S.-J., C.-Y. Tam, and H.-I. Jeong, 2016: How do the strength and type of ENSO affect SST predictability in coupled models. Sci. Rep., 6, 33790, https://doi.org/10.1038/srep33790.

, - — , and J.-S. Kug, 2019: How does ENSO diversity limit the skill of tropical Pacific precipitation forecasts in dynamical seasonal predictions? Climate Dyn., 53, 5815-5831, https:// doi.org/10.1007/s00382-019-04901-2.

Su, J., T. Li, and R. Zhang, 2014: The initiation and developing mechanisms of central Pacific El Niños. J. Climate, 27, 44734485, https://doi.org/10.1175/JCLI-D-13-00640.1.

Timmermann, A., 2003: Decadal ENSO amplitude modulations: A nonlinear paradigm. Global Planet. Change, 37, 135-156, https://doi.org/10.1016/S0921-8181(02)00194-7.

, and Coauthors, 2018: El Niño-Southern Oscillation complexity. Nature, 559, 535-545, https://doi.org/10.1038/s41586018-0252-6.

Vimont, D. J., J. M. Wallace, and D. S. Battisti, 2003: The seasonal footprinting mechanism in the Pacific: Implications for ENSO. J. Climate, 16, 2668-2675, https://doi.org/10.1175/15200442(2003)016<2668:TSFMIT>2.0.CO;2.

Wang, C., C. Deser, J.-Y. Yu, P. DiNezio, and A. Clement, 2017: El Niño and Southern Oscillation (ENSO): A review. Coral Reefs of the Eastern Tropical Pacific, P. W. Glynn, D. P. Manzello, and I. C. Enochs, Eds., Springer, 85-106, https://doi.org/ 10.1007/978-94-017-7499-4_4.

Wang, X., C. Guan, R. X. Huang, W. Tan, and L. Wang, 2019: The roles of tropical and subtropical wind stress anomalies in the El Niño Modoki onset. Climate Dyn., 52, 6585-6597, https:// doi.org/10.1007/s00382-018-4534-3.

Weng, H., K. Ashok, S. K. Behera, S. A. Rao, and T. Yamagata, 2007: Impacts of recent El Niño Modoki on dry/wet conditions in the Pacific rim during boreal summer. Climate Dyn., 29, 113-129, https://doi.org/10.1007/s00382-007-0234-0.

, S. K. Behera, and T. Yamagata, 2009: Anomalous winter climate conditions in the Pacific rim during recent El Niño Modoki and El Niño events. Climate Dyn., 32, 663-674, https:// doi.org/10.1007/s00382-008-0394-6.

Xie, R., and F.-F. Jin, 2018: Two leading ENSO modes and El Niño types in the Zebiak-Cane model. J. Climate, 31, 1943-1962, https://doi.org/10.1175/JCLI-D-17-0469.1.

Xie, S.-P., and S. G. H. Philander, 1994: A coupled ocean-atmosphere model of relevance to the ITCZ in the eastern Pacific. Tellus, 46A, 340-350, https://doi.org/10.3402/tellusa.v46i4.15484.

Xu, K., C. Zhu, and J. He, 2012: Linkage between the dominant modes in Pacific subsurface ocean temperature and the two type ENSO events. Chin. Sci. Bull., 57, 3491-3496, https:// doi.org/10.1007/s11434-012-5173-4.

, ——, and — 2013: Two types of El Niño-related Southern Oscillation and their different impacts on global land 
precipitation. Adv. Atmos. Sci., 30, 1743-1757, https:// doi.org/10.1007/s00376-013-2272-3.

, R. X. Huang, W. Wang, C. Zhu, and R. Lu, 2017a: Thermocline fluctuations in the equatorial Pacific related to the two types of El Niño events. J. Climate, 30, 6611-6627, https://doi.org/10.1175/JCLI-D-16-0291.1.

, C.-Y. Tam, C. Zhu, B. Liu, and W. Wang, 2017b: CMIP5 projections of two types of El Niño and their related tropical precipitation in the twenty-first century. J. Climate, 30, 849864, https://doi.org/10.1175/JCLI-D-16-0413.1.

, Q.-L. Huang, C.-Y. Tam, W. Wang, S. Chen, and C. Zhu, 2019a: Roles of tropical SST patterns during two types of ENSO in modulating wintertime rainfall over southern China. Climate Dyn., 52, 523-538, https://doi.org/10.1007/s00382-0184170-y.

_- W. Wang, B. Liu, and C. Zhu, 2019b: Weakening of the El Niño amplitude since the late 1990s and its link to decadal change in the North Pacific climate. Int. J. Climatol., 39, 41254138, https://doi.org/10.1002/joc.6063.

Yang, S., Z. Li, J. Yu, X. Hu, W. Dong, and S. He, 2018: El NiñoSouthern Oscillation and its impact in the changing climate. Natl. Sci. Rev., 5, 840-857, https://doi.org/10.1093/nsr/nwy046.

Yeh, S.-W., X. Wang, C. Wang, and B. Dewitte, 2015: On the relationship between the North Pacific climate variability and the central Pacific El Niño. J. Climate, 28, 663-677, https:// doi.org/10.1175/JCLI-D-14-00137.1.

— D.-W. Yi, M.-K. Sung, and Y. H. Kim, 2018: An eastward shift of the North Pacific Oscillation after the mid-1990s and its relationship with ENSO. Geophys. Res. Lett., 45, 6654-6660, https://doi.org/10.1029/2018GL078671.

Yu, J.-Y., and H.-Y. Kao, 2007: Decadal changes of ENSO persistence barrier in SST and ocean heat content indices: 19582001. J. Geophys. Res., 112, D13106, https://doi.org/10.1029/ 2006JD007654.

, and S. T. Kim, 2011: Relationships between extratropical sea level pressure variations and the central Pacific and eastern Pacific types of ENSO. J. Climate, 24, 708-720, https://doi.org/ 10.1175/2010JCLI3688.1.

, and B. S. Giese, 2013: ENSO diversity in observations. U.S. CLIVAR Variations, Vol. 11, No. 2, U.S. CLIVAR Program, Washington, DC, 1-5.
, and S.-W. Fang, 2018: The distinct contributions of the seasonal footprinting and charged-discharged mechanisms to ENSO complexity. Geophys. Res. Lett., 45, 6611-6618, https:// doi.org/10.1029/2018GL077664.

_ - H.-Y. Kao, and T. Lee, 2010: Subtropics-related interannual sea surface temperature variability in the central equatorial Pacific. J. Climate, 23, 2869-2884, https://doi.org/10.1175/2010JCLI3171.1.

_- M.-M. Lu, and S. T. Kim, 2012a: A change in the relationship between tropical central Pacific SST variability and the extratropical atmosphere around 1990. Environ. Res. Lett., 7, 034025, https://doi.org/10.1088/1748-9326/7/3/034025.

_ - Y. Zou, S. T. Kim, and T. Lee, 2012b: The changing impact of El Niño on US winter temperatures. Geophys. Res. Lett., 39, L15702, https://doi.org/10.1029/2012GL052483.

_, X. Wang, S. Yang, H. Paek, and M. Chen, 2017: The changing El Niño-Southern Oscillation and associated climate extremes. Climate Extremes: Patterns and Mechanisms, Geophys. Monogr., Vol. 226, Amer. Geophys. Union, 1-38, https:// doi.org/10.1002/9781119068020.CH1.

Yuan, Y., and S. Yang, 2012: Impacts of different types of El Niño on the East Asian climate: Focus on ENSO cycles. J. Climate, 25, 7702-7722, https://doi.org/10.1175/JCLI-D-11-00576.1.

Zhang, W., F.-F. Jin, J. Li, and H.-L. Ren, 2011: Contrasting impacts of two-type El Niño over the western North Pacific during boreal autumn. J. Meteor. Soc. Japan, 89, 563-569, https://doi.org/10.2151/jmsj.2011-510.

— _ _ J.-X. Zhao, L. Qi, and H.-L. Ren, 2013: The possible influence of a nonconventional El Niño on the severe autumn drought of 2009 in southwest China. J. Climate, 26, 8392-8405, https://doi.org/10.1175/JCLI-D-12-00851.1.

,$- \ldots$, and A. Turner, 2014: Increasing autumn drought over southern China associated with ENSO regime shift. Geophys. Res. Lett., 41, 4020-4026, https://doi.org/10.1002/2014GL060130.

Zheng, F., X.-H. Fang, J.-Y. Yu, and J. Zhu, 2014: Asymmetry of the Bjerknes positive feedback between the two types of El Niño. Geophys. Res. Lett., 41, 7651-7657, https://doi.org/ 10.1002/2014GL062125.

- _ _ J. Zhu, J.-Y. Yu, and X.-C. Li, 2016: Modulation of Bjerknes feedback on the decadal variations in ENSO predictability. Geophys. Res. Lett., 43, 12560-12 568, https:// doi.org/10.1002/2016GL071636. 